\title{
ESTIMATES OF MASS AND ENERGY OF DIFFERENT GENETIC MATERIAL EUCALYPTUS ${ }^{1}$
}

Mateus Alves de Magalhães ${ }^{2 *}$, Angélica de Cássia Oliveira Carneiro ${ }^{3}$, Benedito Rocha Vital ${ }^{3}$, Carlos Miguel Simões da Silva ${ }^{2}$, Marina Moura de Souza ${ }^{2}$ and Lucas de Freitas Fialho ${ }^{2}$

\footnotetext{
${ }^{1}$ Received on 20.10.2013 accepted for publication on 09.11.2016.

${ }^{2}$ Universidade Federal de Viçosa, Programa de Pós-Graduação em Ciência Florestal. E-mail: <mateusmagalhaes91@gmail.com>, $<$ karmiguel@yahoo.com.br>,<mourasouzam@gmail.com> and <1.freitasfialho@gmail.com>.

${ }^{3}$ Univercidade Federal de Viçosa, Departamento de Engenharia Florestal. E-mail: < cassiacarneiro@ufv.br>and < bvital@ufv.br>. *Corresponding author.
}

\begin{abstract}
The use of forest biomass or its derived charcoal as firewood can generate environmental and economic advantages for the Brazilian energy matrix. In this context, the main objective was to evaluate the energy potential of certain eucalyptus genetic materials, which are used by the charcoal production sector. We have evaluated six materials of Eucalyptus ssp. at the age of seven years from commercial plantations, spaced $3 \times 3 \mathrm{~m}$, grown in the Alto Vale do Jequitinhonha, in Minas Gerais. Based on the production data, the average annual increment and the physical and chemical analyzes of the wood and the charcoal produced with it, we have estimated parameters to compare the potential of each genetic material, such as mass and energy of wood and charcoal per hectare, as well as the energy density. The results show that a material of Eucalyptus urophylla has greater energetic potential in relation to the others because it presents higher energy/ hectare estimated for its wood and consequently for charcoal produced with it. However, a material of Eucalyptus cloeziana presented a higher energetic density of the wood and its charcoal, showing advantages mainly in the transport.
\end{abstract}

Keywords: Charcoal; Wood; Energetic potential.

\section{ESTIMATIVAS DE MASSA E ENERGIA DE DIFERENTES MATERIAIS GENÉTICOS DE EUCALIPTO}

\begin{abstract}
RESUMO - O uso da biomassa florestal como lenha ou seu derivado carvão vegetal, pode gerar vantagens ambientais e econômicas para a matriz energética brasileira. Nesse contexto, o objetivo principal foi avaliar o potencial energético de alguns materiais genéticos de eucalipto, que são utilizados no setor de produção de carvão vegetal. Foram analisados seis materiais de Eucalyptus ssp. na idade de sete anos provenientes de plantios comerciais, com espaçamento $3 \times 3$ m, cultivados no Alto Vale do Jequitinhonha, em Minas Gerais. Baseando-se nos dados de produção, no incremento médio anual e nas análises físicas e químicas da madeira e do carvão com ela produzidos, foram estimados parâmetros para se comparar o potencial de cada material genético, como a massa e a energia da madeira e do carvão por hectare, além da densidade energética. Os resultados demonstram que um material de Eucalyptus urophylla possui maior potencial energético em relação aos demais, por apresentar maior energia/hectare estimada para sua madeira e consequentemente para seu carvão produzido. Mas um material de Eucalyptus cloeziana apresentou maior densidade energética da madeira e de seu carvão, mostrando vantagens principalmente no transporte.
\end{abstract}

Palavras-Chave: Carvão; Madeira; Potencial energético

Revista Árvore. 2017;41(3):e410302

http://dx.doi.org/10.1590/1806-90882017000300002 


\section{INTRODUCTION}

The Brazilian energy matrix for the year 2015 was based on petroleum and its derivatives with $37.3 \%$, mineral coal with $5.9 \%$, natural gas with $13.7 \%$, nuclear energy with $1.3 \%$ and others with $0.6 \%$, adding up to a total of $58.8 \%$ for non-renewable sources. Renewable sources accounted for $41.2 \%$ of the matrix, and are subdivided into hydro power with $11.3 \%$, sugarcane products with $16.9 \%$, wood and charcoal with $8.2 \%$, and others with $4.7 \%$ (EPE, 2016).

Wood and charcoal, which accounted for 44 percent of the Brazilian energy matrix in the 1970s, now account for less than ten percent. This decrease is justified by the introduction of more efficient energy resources, replacing a significant percentage of renewable energy sources predominantly based on forest biomass, by non-renewable sources such as oil and its derivatives (Tolmasquim et al., 2007). Prospects for 2020 and 2030 show the continuity of this decrease (Rodrigues and Halmeman, 2012).

For Brito (2007), these energies of fossil origin, in addition to being non-renewable sources which make the energy matrix somewhat uncertain for the future, they also have negative effects over the environment. In this context, study and investment are justified in order to develop alternative sources and improve existing ones, such as those of forest biomass that have lost part of their relevance over the last decades. It is worth emphasizing the importance of using wood from reforestation areas to produce "clean" energy, following environmental and social precepts.

One of the focuses for the improvement of biomass characteristics is through forest improvement. Nowadays, we have sought the development of genetic materials with a higher energy vocation in order to present features exclusively geared to this sector. In Brazil, the genetic improvements applied to the genus Eucalyptus are a potential option for the increase in production of this wood (Botrel et al., 2007). The genus Eucalyptus represents a large part of the forests planted for energetic purposes due to the adaptation of this genus to the edaphoclimatic conditions and its rapid growth, in addition to Brazil already holding high scientific and technological level for procedures in the several areas of eucalyptus culture (Alzate et al., 2005).
Thus, the main objective of this work was to evaluate the energy potential of certain genetic materials from eucalyptus which are used by the charcoal production sector. The specific objectives were to determine the density, higher calorific value, dry mass, energy/hectare and energy density of these different genetic materials and of the charcoal produced with them, in order to classify them in relation to their energy potential.

\section{MATERIALAND METHODS}

\subsection{Materials used}

In order to carry out this work, we have used six genetic materials of eucalyptus (Table 1), all at the age of 7 years, collected from commercial plantations belonging to Arcelor Mittal BioEnergia LTDA, located in the municipality of Itamarandiba. The planting site is located at 1,056 meters altitude, with average rainfall of $1,164.56 \mathrm{~mm}$, temperature ranging between 16.8 and $26.8^{\circ} \mathrm{C}$ and an average relative humidity of $69 \%$.

Six trees of medium diameter were selected for each of the genetic materials, totaling thirty-six trees (samples). The trees were collected from commercial plantations with average spacing of $3 \mathrm{~m} \times 3 \mathrm{~m}$.

\subsection{Sample preparation}

We have removed disks from the trees at 0,25 , 50,75 and $100 \%$ of the commercial height of the trunk. From these, two opposite wedges were passed through the medulla, which were used to determine the basic density of the wood. The rest of the disk samples were taken for the production of charcoal and for determining the higher calorific value of the wood.

\subsection{Determination of basic wood density}

The analysis was done following the procedures of the water immersion method described by (Vital, 1984). The wedge-shaped samples were kept submerged in water in order to create saturation of the wood, after which their volume was measured in water by means of a scale. They were dried in an oven at 103 $\pm 2{ }^{\circ} \mathrm{C}$ until constant weight, so the anhydrous wood mass was obtained. The basic density of the wood was calculated by dividing the dry wood mass by its saturated volume and the value for each disk was obtained from the arithmetic mean of its respective wedges.

Revista Árvore. 2017;41(3):e410302

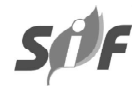


Table 1 - General information about the genetic materials used in the study. Tabela 1 - Informações gerais sobre os materiais genéticos utilizados no estudo.

\begin{tabular}{llc}
\hline & 1 & Eucalyptus cloeziana \\
\hline \multirow{3}{*}{ Genetic material } & 2 & Spontaneous hybrid of Eucalyptus urophylla \\
& 3 & Eucalyptus urophylla x Eucalyptus grandis \\
& 4 & Spontaneous hybrid of Eucalyptus urophylla \\
& 5 & Spontaneous hybrid of Eucalyptus urophylla \\
& 6 & Spontaneous hybrid of Eucalyptus urophylla \\
\hline
\end{tabular}

\subsection{Determination of the higher calorific value}

The higher calorific value of the wood, as well as of its charcoal was determined according to the methodology described by ABNT NBR 8633 (ABNT, 1984), using an adiabatic calorimetric pump.

\subsection{Carbonization and gravimetric yields}

The samples for carbonization were taken from the rest of the disks used to determine the basic density of the wood; these were mixed together and we have obtained a composite sample. The composite sample was then oven dried at $103 \pm 2{ }^{\circ} \mathrm{C}$ until constant weight.

The carbonizations were carried out in a laboratory furnace with electric heating, using about $250 \mathrm{~g}$ of wood which were inserted in a metallic container with nominal dimensions of $30 \mathrm{~cm}$ in length and $12 \mathrm{~cm}$ in diameter.

The total carbonization time of the wood was five hours, with an average heating rate of $1.56^{\circ} \mathrm{C} /$ minute, the initial temperature being $30^{\circ} \mathrm{C}$ and the final temperature, $450^{\circ} \mathrm{C}$. After carbonization, we have determined the gravimetric charcoal yield based on the dry mass of the wood.

\subsection{Apparent relative density}

The apparent relative density of the charcoal was determined according to the method proposed by Vital (1984), using a hydrostatic balance to determine the displaced volume. Samples of approximately $5 \mathrm{~g}$ of charcoal were weighed to obtain the mass and subsequently immersed in mercury to determine the displaced volume.

\subsection{Estimates for dry mass, energy per hectare and energy density}

The dry mass of shelled wood expressed in $(\mathrm{t} /$ ha.year) was obtained by multiplying the average annual increment ( $\mathrm{m}^{3} /$ ha.year) by the basic density of the wood $\left(\mathrm{kg} / \mathrm{m}^{3}\right)$.
The charcoal mass in ( $t /$ ha.year) was determined by multiplying the dry mass of wood by the gravimetric yield of the charcoal.

In order to calculate the amount of energy per hectare of wood and charcoal expressed in (kwh/ha.year), their respective mass ( $\mathrm{kg} / \mathrm{ha}$.year) was multiplied by their corresponding higher calorific value (kcal/kg).

In order to calculate the energy density of wood as well as that of charcoal, expressed in $\left(\mathrm{kwh} / \mathrm{m}^{3}\right)$, we have multiplied the corresponding density $\left(\mathrm{kg} / \mathrm{m}^{3}\right)$ by its respective higher calorific value $(\mathrm{kcal} / \mathrm{kg})$.

It was assumed that, $1 \mathrm{kWh}$ corresponds to 859.18 kcal.

\subsection{Statistical analysis of the experiment}

The experiment was analyzed according to a completely randomized design, with six genetic materials of eucalyptus and six replicates, totaling 36 trees.

All data were submitted to the Cochran and Bartlett (normality variance homogeneity) and Lilliefors (normality) tests.

The data were submitted to analysis of variance (ANOVA) and whenever significant differences were established, the treatments were compared by means of the Tukey test at 5\% probability.

\section{RESULTS}

\subsection{Properties and mass and energy estimates for wood}

It can be observed that the value obtained for the annual average increment (AAI) without peel was statistically higher for genetic material 5 (Eucalyptus urophylla spontaneous hybrid), and genetic material 1 (Eucalyptus cloeziana) had a lower AAI value.

In regards to the basic density, we have verified that the genetic material 1 presented the highest average 
value, and this one was significantly different from the others. In contrast, materials 2 and 5 (spontaneous hybrids of Eucalyptus urophylla) presented the lowest values for this particular property.

Genetic materials 4 and 5 (spontaneous hybrids of Eucalyptus urophylla) presented higher average values of dry mass, and were statistically different from the others which can be explained by the fact that both presented the highest average annual increments, even if they were not the ones with the highest densities. The genetic materials 1 and 6 (spontaneous hybrid of Eucalyptus urophylla) were the ones with the lowest values for this variable.

It is observed a superior average for the higher calorific value of the wood of genetic material 3 (Eucalyptus grandis $\mathrm{x}$ Eucalyptus urophylla), while genetic materials 2 and 5 presented the smallest average values for this property.

From an energetic point of view, it can be observed that the most interesting genetic materials are 4 and 5 , since they had the highest average values of energy/ hectare, provided they obtained the highest amount of dry mass per hectare/year. Materials 1 and 6 are the least indicated for energy production, since they have the lowest average values among the materials we have analyzed.

The genetic material that presented the highest energy density was 1 , showing that its wood produces more energy for the same unit of volume. In contrast, genetic material 2 had the lowest energy density.

\subsection{Properties and mass and energy estimates for the charcoal}

Regarding the gravimetric yield, genetic material 1 (Eucalyptus cloeziana) presented the highest average value for gravimetric charcoal yield and was statistically different from the others; genetic material 3 (Eucalyptus urophylla $\mathrm{x}$ Eucalyptus grandis) presented the lowest value.

Genetic materials 4 and 5 (both spontaneous hybrids of Eucalyptus urophylla) showed, in a statistically significant way, the highest values of mass for charcoal, namely 7.9 and $8.2 \mathrm{t} / \mathrm{ha}$.year respectively.

As for the higher calorific value of the charcoal, the highest average values were observed in genetic materials 3, 4, 5 and 6 (spontaneous Eucalyptus urophylla

Revista Árvore. 2017;41(3):e410302 hybrids), showing no statistical difference among them but differing significantly from materials 1 and 2 (spontaneous hybrids of Eucalyptus urophylla), which presented the lowest average values for this particular property.

When it comes to the amount of energy stored per hectare/year estimated for charcoal, genetic materials 4 and 5 presented the highest values, and we have observed the lowest values for this variable in materials 1 and 6 .

The charcoal produced from genetic material 1 presented the highest average value for apparent density, differing significantly from the others. Contrariwise, genetic materials 2 and 5 showed the lowest values, although these values have not differed statistically. This result presented by genetic material 1 can be explained by the wood that gave rise to it having the highest basic density in relation to the studied materials, since the higher the basic density of the wood, the greater the density of the charcoal produced by it.

The energy density of the charcoal followed patterns similar to the energy density of the corresponding wood, where genetic materials 1 and 2 presented respectively the highest and lowest values.

\section{DISCUSSION}

\subsection{Properties and mass and energy estimates for wood}

The average annual increment obtained by forestbased companies in the year 2015 for eucalyptus plantations was $36 \mathrm{~m}^{3} /$ ha.year (IBÁ, 2016). Only genetic materials 2, 4 and 5 presented higher AAI than those observed in forestry companies. The observed differences between the materials of this work can be attributed to the species and also to the different conditions of site, climate, silvicultural management, etc. A higher average annual increment associated with a higher wood density contributes to a higher dry mass production for a given genetic material, and the AAI also has a greater influence when compared to the density of the wood.

The basic density results found in the present study, 0.49 to $0.64 \mathrm{~g} / \mathrm{cm}^{3}$, cover a larger range than those observed by certain authors, possibly reflecting mass and energy estimates. Santos et al. (2011) reported that denser woods are interesting for the production of charcoal, since thermal degradation of the wood 
Table 2 - Average values for the average annual increment without bark, basic density, dry mass, higher calorific value, energy and energetic density for wood of different clones of eucalyptus.

Tabela 2 - Valores médios de incremento médio anual sem casca, densidade básica, massa seca, poder calorífico superior, energia e densidade energética para a madeira dos diferentes materiais genéticos de eucalipto.

\begin{tabular}{ccccccr}
\hline Genetic & \multicolumn{5}{c}{ Wood } \\
\cline { 2 - 7 } material & IMAsc(m ${ }^{3} /$ ha.year $)$ & DB $\left(\mathrm{g} / \mathrm{cm}^{3}\right)$ & MS $(\mathrm{t} / \mathrm{ha} \cdot \mathrm{year})$ & PCS $(\mathrm{kcal} / \mathrm{kg})$ & EM $(\mathrm{kwh} / \mathrm{ha} \cdot \mathrm{year})$ & $\mathrm{DEM}\left(\mathrm{kwh} / \mathrm{m}^{3}\right)$ \\
\hline $\mathbf{1}$ & $24.8 \mathrm{~d}$ & $0.64 \mathrm{a}$ & $15.9 \mathrm{~d}$ & $4539.3 \mathrm{ab}$ & $83937.3 \mathrm{~d}$ & $3387.8 \mathrm{a}$ \\
$\mathbf{2}$ & $38.8 \mathrm{~b}$ & $0.49 \mathrm{e}$ & $18.9 \mathrm{~b}$ & $4466.8 \mathrm{~b}$ & $98410.8 \mathrm{~b}$ & $2534.7 \mathrm{e}$ \\
$\mathbf{3}$ & $34.2 \mathrm{c}$ & $0.52 \mathrm{c}$ & $17.8 \mathrm{c}$ & $4577.3 \mathrm{a}$ & $94608.9 \mathrm{c}$ & $2763.0 \mathrm{c}$ \\
$\mathbf{4}$ & $40.4 \mathrm{~b}$ & $0.56 \mathrm{~b}$ & $22.8 \mathrm{a}$ & $4494.5 \mathrm{ab}$ & $119062.4 \mathrm{a}$ & $2950.1 \mathrm{~b}$ \\
$\mathbf{5}$ & $46.9 \mathrm{a}$ & $0.49 \mathrm{e}$ & $23.1 \mathrm{a}$ & $4450.1 \mathrm{~b}$ & $119496.2 \mathrm{a}$ & $2547.8 \mathrm{de}$ \\
$\mathbf{6}$ & $31.0 \mathrm{c}$ & $0.50 \mathrm{~d}$ & $15.6 \mathrm{~d}$ & $4493.1 \mathrm{ab}$ & $2634.8 \mathrm{~d}$ \\
\hline
\end{tabular}

IMAsc = average annual increment without bark; DB = basic density; MS = dry mass PCS = higher calorific value; EM = estimated energy per hectare; DEM = energy density. Averages followed by the same lowercase letter across the column do not differ from each other at $5 \%$ significance by the Tukey test.

Table 3 - Displays values of gravimetric yield, higher calorific value, apparent density, mass and energy estimates for charcoal produced from different clones of eucalyptus.

Tabela 3 - Apresenta valores médios de rendimento gravimétrico, poder calorifico superior, densidade aparente, estimativas de massa e energia para o carvão produzido a partir do diferentes materiais genéticos de eucalipto.

\begin{tabular}{ccccccc}
\hline \multirow{2}{*}{$\begin{array}{c}\text { Cenetic } \\
\text { material }\end{array}$} & RGCV $(\%)$ & MCV (t/ha.year) & PCS $(\mathrm{kcal} / \mathrm{kg})$ & ECV $(\mathrm{kwh} / \mathrm{ha} \cdot \mathrm{year})$ & $\mathrm{DRA}\left(\mathrm{g} / \mathrm{cm}^{3}\right)$ & $\mathrm{DECV}\left(\mathrm{kwh} / \mathrm{m}^{3}\right)$ \\
\cline { 2 - 6 } & $36.6 \mathrm{a}$ & $5.8 \mathrm{~d}$ & $7306.6 \mathrm{~b}$ & $49426.2 \mathrm{~d}$ & $0.48 \mathrm{a}$ & $4083.9 \mathrm{a}$ \\
2 & $36.0 \mathrm{ab}$ & $6.8 \mathrm{~b}$ & $7309.3 \mathrm{~b}$ & $57915.6 \mathrm{~b}$ & $0.33 \mathrm{c}$ & $2784.2 \mathrm{~d}$ \\
3 & $34.6 \mathrm{c}$ & $6.1 \mathrm{c}$ & $7539.6 \mathrm{a}$ & $53838.9 \mathrm{c}$ & $0.38 \mathrm{~b}$ & $3342.1 \mathrm{~b}$ \\
4 & $34.8 \mathrm{bc}$ & $7.9 \mathrm{a}$ & $7562.2 \mathrm{a}$ & $69663.0 \mathrm{a}$ & $0.39 \mathrm{~b}$ & $3443.1 \mathrm{~b}$ \\
5 & $35.4 \mathrm{abc}$ & $8.2 \mathrm{a}$ & $7546.8 \mathrm{a}$ & $71832.6 \mathrm{a}$ & $0.33 \mathrm{c}$ & $2909.3 \mathrm{~cd}$ \\
6 & $35.3 \mathrm{abc}$ & $5.5 \mathrm{~d}$ & $7508.8 \mathrm{a}$ & $48257.8 \mathrm{~d}$ & $0.37 \mathrm{bc}$ & $3234.9 \mathrm{bc}$ \\
\hline
\end{tabular}

$\mathrm{RGCV}=$ gravimetric yield for charcoal; $\mathrm{MCV}=$ estimated mass of charcoal per hectare; PCS = higher calorific value; ECV $=$ estimated energy for charcoal per hectare; DRA = apparent relative density; DECV = energy density of charcoal. Averages followed by the same lowercase letter across the column do not differ from each other at $5 \%$ significance by the Tukey test.

occurs during the carbonization process and about $60 \%$ of its mass is lost. In light of this, the higher the wood density, the greater the mass of charcoal produced for a given volume. Castro (2011) observed values ranging from 0.52 to $0.56 \mathrm{~g} / \mathrm{cm}^{3}$ for eucalyptus clones also at 7 years of age. Alzate et al. (2005) evaluated a clone of Eucalyptus urophylla $x$ Eucalyptus grandis at the age of 8 years, and obtained an average basic density value of $0.49 \mathrm{~g} / \mathrm{cm}^{3}$; the same authors reported that according to literature, the basic density of wood varies in function of certain factors such as: tree growth rate, climate, silvicultural treatments, age, whether within the same species or across different species. The species factor can be explained by the higher density value presented by genetic material 1, since Eucalyptus cloeziana is cited in literature as one of the species with the highest density among the genus Eucalyptus.

The dry mass estimates varied between 15.6 and $23.1 \mathrm{t} /$ ha.year. The values are slightly different from those observed in literature, due to differences in productivity and basic density of the materials used by other authors. Santos (2010) studied different genetic materials of eucalyptus at 7 years of age, and observed an average dry mass of wood ranging from 21.9 to $26.9 \mathrm{t} /$ ha.year. Rocha (2011) obtained an average value of 17.23t/ha.year for Eucalyptus grandis $x$ Eucalyptus camaldulensis at 7 years of age, at spacing of $3 \times 3$ meters. The highest values of dry mass for wood that were found, were largely influenced by the AAIs of their respective materials. As a consequence, these higher values contributed considerably to energy production/hectare, since the calorific value of the wood did not present great statistical differences to the materials used.

The figures for the higher calorific value observed in this work varied between 4,450.08 and 4,577.33kcal/ $\mathrm{kg}$ and are very similar to the values found by the authors mentioned below. Castro (2011) evaluated eucalyptus clones at 7 years of age and found average values for the higher calorific value ranging from $4,481.65$ to 
4,617.17kcal/kg. In a study, Quirino et al. (2005) found higher calorific values of Eucalyptus urophylla wood to be between $4,422.0$ and $4,595.0 \mathrm{kcal} / \mathrm{kg}$. Santos et al. (2011) reported that, according to literature, certain factors such as the chemical composition of the wood can influence its calorific value, mainly by means of the extractive and lignin contents, which are also variable across different species.

The estimated energy for the materials ranged from $81,783.3$ to $11,9496.2 \mathrm{kwh} /$ ha.year, with these results being lower than those observed by Santos (2010), from $111,388.4$ to $143,678.9 \mathrm{kwh} /$ ha.year but higher than those found by Rocha (2011), with an average value of $76,223.63 \mathrm{kwh} / \mathrm{ha}$.year.

The average values of energy density observed for the genetic material used in the present work are between $2,534.7$ and $3,387.8 \mathrm{kwh} / \mathrm{m}^{3}$, showing greater variation than those observed by Castro (2011) when evaluating eucalyptus clones, who found energy density ranging from $2,801.0$ to $2,943.0 \mathrm{kwh} / \mathrm{m}^{3}$ for materials at 7 years of age. These results are influenced by the basic density and the higher calorific value of the wood. Therewith, the result presented by the genetic material 1 is explained. The energy density must be taken into account for the transportation, since the amount of energy transported per unit of volume is higher for wood that has higher energy density, thus reducing transport costs for a given energy content.

\subsection{Properties, and mass and energy estimates for charcoal}

The charcoal yield values observed in this study, which ranged from 34.6 to $36.6 \%$, can be considered satisfactory since Arantes (2009), when evaluating a hybrid clone of Eucalyptus urophylla and Eucalyptus grandis at six years of age, found yields varying from 33.68 to $35.07 \%$, using final carbonization temperature of $450^{\circ} \mathrm{C}$ and heating rate of $1.67^{\circ} \mathrm{C}$. Santiago and Andrade (2005) found an average carbonization yield of $26.91 \%$ for Eucalyptus urophylla wood, using a final temperature of $400^{\circ} \mathrm{C}$ and a heating rate of $11.98^{\circ} \mathrm{C} / \mathrm{min}$, this low yield can be explained by the high heating rate used by the authors. According to Pinheiro et al. (2005) the higher this rate, the lower the charcoal yield.

The results of mass of charcoal were higher than those found by Rocha (2011), which ranged from 5.11 to $6.16 \mathrm{t} / \mathrm{h}$. year. Santos (2010) obtained average values between 6.2 and $8.1 \mathrm{t} /$ ha.year. We have observed the lowest values for charcoal mass in the genetic materials 1 and 6 . The highest values were observed due to the high dry mass values of the wood. Thus, the ability to produce more dry wood mass may indicate which genetic materials will present higher mass values of charcoal produced with them.

Rocha (2011) obtained higher calorific values, similar to those observed in the present study, for a hybrid clone of Eucalyptus grandis $x$ Eucalyptus camaldulensis at seven years of age, which ranged from $7,834 \mathrm{kcal} /$ $\mathrm{kg}$ to $7,900 \mathrm{kcal} / \mathrm{kg}$. Oliveira et al. (2010) observed average values for the higher calorific value of charcoal ranging from $8,023 \mathrm{kcal} / \mathrm{kg}$ to $8,339 \mathrm{kcal} / \mathrm{kg}$ for Eucalyptus pellita at five years of age. The differences found in these results may be related to the use of different carbonization steps. The calorific value of charcoal is related to its fixed carbon content, which in turn increases with the degradation of the wood. However, the wood exposed to higher carbonization temperatures and for a longer time, suffers greater degradation and consequent losses in the apparent density and resistance of the charcoal (Castro, 2011).

The best energy/hectare results in materials 4 and 5 are the consequence of having a higher charcoal mass than the others, and the higher calorific value of the charcoal did not significantly influence these results since it did not show large statistical differences.

The average values of apparent density for the charcoal observed in this study ranged from 0.33 to $0.48 \mathrm{~g} / \mathrm{cm}^{3}$. These are similar to those found by Oliveira et al. (2010), which varied between $0.35 \mathrm{~g} / \mathrm{cm}^{3}$ and $0.39 \mathrm{~g} /$ $\mathrm{cm}^{3}$ and those of Frederico (2009), who obtained average values of apparent density ranging from 0.27 to $0.33 \mathrm{~g} /$ $\mathrm{cm}^{3}$ for charcoal produced from the clones of Eucalyptus sp. According to Santos (2010), the higher the wood density, the greater the density of the charcoal produced from it, and this is an important parameter to be considered when the charcoal is destined for steel use.

The high apparent density observed for the charcoal from genetic material 1 have contributed significantly to its higher energy density in relation to the others, since the calorific value of its charcoal was the lowest among the studied materials. It is also observed a higher value for the energy density of the charcoal in relation to the wood that gave rise to it; this can be explained because carbon fixation occurs in the charcoal during

Revista Árvore. 2017;41(3):e410302

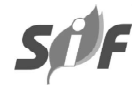


the carbonization process, contributing to the increase of its higher calorific value than that of its wood. Considering that the energy density of charcoal is greater than the wood it was made from, it is possible to transport the charcoal to greater distances in relation to wood.

\section{CONCLUSIONS}

Genetic materials 4 and 5 (both spontaneous hybrids of Eucalyptus urophylla) stood out in relation to the others for energetic purposes.

Genetic material 1 (Eucalyptus cloeziana) presented higher energetic density for wood and charcoal, showing advantages mainly at the time of transportation.

When choosing genetic materials for energy production it is recommended that one uses those with higher volumetric productivity, higher basic wood density and the calorific value of both wood and charcoal.

\section{ACKNOWLEDGEMENTS}

The authors would like to thank Fapemig (Foundation for Research Support of the State of Minas Gerais) for funding the project; EMBRAPAFLORESTAS and CNPq for providing research grants; Arcelor Mittal, for the donation of wood; the Federal University of Viçosa and the employees of the Wood Panel and Energy Laboratory (LAPEM / UFV).

\section{REFERENCES}

Alzate SBA, Tomazello Filho M, Piedade SMS. Variação longitudinal da densidade básica da madeira de clones de Eucalyptus grandis Hill ex Maiden, E. saligna Sm. e E. grandis x urophylla. Scientia Forestalis. 2005;68:87-95.

Arantes MDC. Variação nas características da madeira e do carvão vegetal de um híbrido de Eucalyptus grandis W.Hill ex Maiden $\mathrm{x}$ Eucalyptus urophylla S.T. Blake [tese]. Lavras: Universidade Federal de Lavras; 2009.

Associação Brasileira de Normas Técnicas ABNT. NBR 8633: carvão vegetal: determinação do poder calorifico. Rio de Janeiro: 1984.

Botrel MCG, Trugilho PF, Rosado SCS, Silva JRM. Melhoramento genético das propriedades do carvão vegetal de Eucalyptus. Revista Árvore. 2007;31(3):391-8
Brito JO. O uso energético da madeira. Estudos Avançados. 2007;21(59):185-93.

Castro AFNM. Efeito da idade e de materiais genéticos de Eucalyptus sp. na madeira e carvão vegetal [dissertação]. Viçosa, MG: Universidade Federal de Viçosa; 2011.

Empresa de Pesquisa Energética - EPE. Balanço Energético Nacional - Relatório Síntese - Ano Base 2015. Rio de Janeiro: 2016.

Frederico PGU. Efeito da região e da madeira de eucalipto nas propriedades do carvão vegetal. [dissertação] Viçosa, MG: Universidade Federal de Viçosa; 2009.

Indústria Brasileira de Árvores - IBÁ. Anuário Estatístico - Ano Base 2015. 2016. p.100

Oliveira AC, Carneiro ACO, Vital BR, Almeida W, Pereira BLC, Cardoso MT. Parâmetros de qualidade da madeira e do carvão vegetal de Eucalyptus pellita F. Muell. Scientia Forestalis. 2010;38(87):431-9.

Pinheiro PCC, Figueiredo FJ, Seye O. Influência da temperatura e da taxa de aquecimento da carbonização nas propriedades do carvão vegetal de Eucalyptus. Biomassa e Energia. 2005;2(2):159-68.

Quirino WF, Vale AT, Andrade APA, Abreu VLS, Azevedo ACS. Poder calorífico da madeira e de materiais ligno-celulósicos. Revista Madeira. (2005):89:100-6.

Rocha MFV. Influência do espaçamento e da idade na produtividade e propriedades da madeira de Eucalyptus grandis x Eucalyptus camaldulensis para energia [dissertação]. Viçosa, MG: Universidade Federal de Viçosa; 2011. 84p.

Rodrigues AS, Halmeman RJ. Matriz energética brasileira: uma reflexão sobre a situação atual e possíveis riscos de "apagões". Bioenergia em Revista. Diálogos. 2012;2(1):11-26.

Santiago AR, Andrade AM. Carbonização de resíduos do processamento mecânico da madeira de eucalipto. Ciência Florestal. 2005;15(1):1-7.

Santos RC. Parâmetros de qualidade da madeira e do carvão vegetal de clones de Eucalipto [tese].

Revista Árvore. 2017;41(3):e410302 
Lavras: Universidade Federal de Lavras; 2010.

Santos RC, Carneiro ACO, Castro AFM, Castro RVO, Bianche JJ, Souza MM et al. Correlações entre os parâmetros de qualidade da madeira e do carvão vegetal de clones de eucalipto. Scientia Forestalis. 2011;39(90):221-30.
Tolmasquim MT, Guerreiro A, Gorini R. Matriz energética brasileira: uma prospectiva. Novos estudos - CEBRAP. 2007(79):47-69.

Vital BR. Métodos de determinação de densidade da madeira. Viçosa, MG: SIF; 1984. (Boletim técnico, 1).

Revista Árvore. 2017;41(3):e410302 